\title{
VIBRATION ANALYSIS ON THE CRANKSHAFT AXIS OF AN INTERNAL COMBUSTION ENGINE
}

\author{
Claudio Marcio Santana ${ }^{1}$, Jose Eduardo Mautone Barros ${ }^{1}$, Helder Alves de Almeida Junior ${ }^{1}$ e \\ Jorgimara de Oliveira Braga ${ }^{1}$.
}

Federal University of Minas Gerais - Av. Antonio Carlos, 6627, Pampulha, Belo Horizonte CEP: 31270-901.

claudiowsantana@gmail.com; mautone@demec.ufmg.br; helder.alves.eng@gmail.com; jmarabraga@hotmail.com

\section{RESUMO}

Vibration problems in internal combustion engines produce premature wear on the internal components of the engine, which contributes both to reduce the lifespan of the engine itself as well as cause discomfort to the occupants of the vehicle. Thus, since it is impossible to totally eliminate vibrations from engines, it is important to understand the sources of vibration production and control them to acceptable levels. The general objective of this paper is to measure the vibration in the areas that undergo greater efforts due to the processes of combustion and mechanical forces. These areas are the fixed bearings located to the extremes of the crankshaft. The specified objective of this study is to correlate these levels of crankshaft engine vibration relative to the fuel used, ethanol and gasoline, and assess the influence of lubricant oils on the vibration levels as a function of the viscosity of the lubricant. The results demonstrated that the vibration intensity of the engine increases with increasing engine speed and load. In all operating conditions, the ethanol-run engine has higher vibration intensities than the gasoline-run engine. For the same type of fuel, an oil of higher viscosity attenuates the level of vibration of the engine. Measurements show an average increase of $18 \%$ of transverse vibration and $12 \%$ of longitudinal vibration in the crankshaft of the engine running on ethanol in relation to gasoline with low viscosity lubricant and $14 \%$ and $10 \%$ with higher viscosity lubricant.

\section{INTRODUÇÃO}

Internal combustion engines are classified according to the burning mode of the fuel in both spark-ignition and compression-ignition engines [1]. Both gasoline and ethanol-powered engines are examples of spark-ignited engines. Thus, the firing of the fuel is initiated with a spark provided by the spark plug [2]. Diesel engines typically run on diesel oil or a blend of diesel and biodiesel. The combustion in these engines occurs spontaneously, due to the airfuel mixture under high pressures and temperatures inside the cylinder [3]. Viscosity is the main property of automotive lubricant oils for internal combustion engines and it also indicates the degree of resistance a lubricant oil allows on two surfaces in relative motion. Lubricant oils undergo changes in their viscosity when subjected to temperature variation and load and these variations can be very different depending on each type of lubricant oils. The SAE nomenclature with two numerical viscosity values indicates that this lubricant is multi- 
viscous and is suitable for engines operating at high temperature gradients, for example SAE 10W30, SAE 20W50 and SAE 5W30 [4]. The viscosity index is a numerical value indicating the viscosity change with respect to temperature variation and load. The higher the value of the viscosity index of a lubricant, lower is the variation of the viscosity with increasing temperature [3, 4]. Today's automotive lubricant oils have a high viscosity index, which allows a quick start in cold temperatures, immediate lubrication at the highest points in the engine when starting, lower oil consumption and efficient lubrication at high temperatures. In general, oils with lower viscosities present better pumping, better cold start, fuel economy and better engine cooling. Oils with higher viscosity have greater protection against wear, better oil film protection and lower oil consumption $[2,4]$.

The engine, due to its constructive and functional characteristics, is the main source of vibration of a vehicle because it is through the engine that the vibrations and noises are transmitted to the body, and consequently felt by the occupants of the car [5]. The vibrations from the engine can be divided into vibrations due to the combustion process, vibrations due to mechanical forces, vibrations due to air flow and combustion gases through the inlet and discharge manifolds [5]. Vibration is generated due to the combustion of the fuel-air mixture inside the combustion chamber triggered by the addition of heat in each of the cylinders. The type of fuel used will influence directly by establishing particular characteristics to this kind of vibration [6]. Spark-ignition engines may use ethanol, gasoline or a mixture of both in any given proportion. Ethanol, in comparison to gasoline, has a higher resistance to both high pressures and temperatures inside the combustion chamber without spontaneously igniting. Such characteristic makes the ignition advance in the ethanol-run engines more advanced in comparison to gas-run engines [2]. This feature will influence the vibration level in both ethanol and gasoline-run engines [5]. Another factor related to the combustion process, which directly influences the vibration level of engines, is the compression ratio. The higher compression ratio, the higher the maximum pressure peak at the end of the compression timing; the higher the forces generated, higher vibration peaks [6]. The most important contributions of the mechanical forces are due to the lateral movements of the pistons, movement of the crankshaft relative to the bearings, movement of the intake and discharge valves and engine design parameters. The vibrations due to the pistons are caused by their impacts on the walls of the cylinders owing to their transverse or inclined movements especially during exhaustion [5]. The vibrations coming from the crankshaft are due to transverse and longitudinal movements owing to the gap (for lubrication) between the shaft and the bearing [6].

Chandratre et al. [7] investigated the influence of viscosity of oil by adding two grades of viscosity in damping coefficient of engine oil. The tests were realized with a four strokes engine with oil SAE 10W30, SAE 15W40, SAE 20W50 and two types of additive added in the three oil at 5\%,10\% and $15 \%$ of additive. The results demonstrated that the presence of additive has significantly improved the damping properties of engine oil and the maximum damping effects was obtained with higher damping coefficient of SAE 20W50 blended with additive with higher viscosity. Chavan et al. [8] correlated the vibration of the plain hydrodynamic journal bearing system with lubricant oil viscosity. The tests were realized with oil SAE 40, SAE 90 and SAE 140 varying load and speed. The results demonstrated that the lubricant viscosity has evident effect on vibrations of the system. SAE 40 shows fewer vibrations at higher speeds, while SAE 140 oils show less vibration at lower speeds. Grajales et al. [9] investigated failures in internal combustion engine by vibration analysis. The tests were realized in engine bench test with pure gasoline and gasoline blend with ethanol 
fuels at $20 \%$ and $30 \%$. Vibrations measurements in engine block in transversal directions demonstrates that changes in the mix seem to have little impact on the performance and behavior of the engine vibration signals. Keskin [10] investigated vibration effect of ethanol and gasoline blends on two stokes spark ignition engine. The experiments were at 1500, 2000 and $2500 \mathrm{rpm}$ engine speed. The results demonstrate that vibration characteristics of engine changed significantly at 1500 and $2000 \mathrm{rpm}$ with gasoline blend with ethanol fuels and the vibration amplitude of the engine with ethanol pure showed a trend of increasing. Uludamar et al. [11] investigated the vibration effect of canola biodiesel, sunflower biodiesel and their blends with low Sulphur diesel fuel. The experiments were realized a four-cylinder, four stokes diesel engine at 1300, 1600, 1900, 2200, 2500 and $2800 \mathrm{rpm}$ engine speed. Vibration measurement were made on engine support to observe engine vibration just before transmitted to chassis. The results demonstrate that vibration amplitude increase with engine speed at every fuel. Up $60 \%$ canola and sunflower biodiesel addition into the Sulphur diesel fuel decreased the vibration level of the diesel engine, up $40 \%$ vibration values significantly improved and for the blend of $80 \%$ the vibration value starts to increase. Addition of canola biodiesel decreased vibration severity more than sunflower biodiesel addition. Gravalos et al. [12] investigate the effects of vibrations on spark ignition engine fueled with gasoline base fuel and gasoline blend with ethanol and methanol fuels at 10\%, 20\% and $30 \%$. The experiments were realized a single cylinder spark ignition engine and were performed at 1000, 1300, 1600 and 1900 a hydraulic dynamometer. The results demonstrate that, in general, vibration amplitude of the fundamental harmonics decrease with increase of load or decrease of engine speeds. The vibration values of gasoline base fuel had higher amplitudes at $1300 \mathrm{rpm}$, gasoline blend with 10\% of methanol fuel had higher amplitudes at $1900 \mathrm{rpm}$. Gasoline blend with $10 \%$ of ethanol fuel gave in comparison with others tests fuels more stable vibration amplitudes. The results are due the changing of the process combustion, which was caused the from the fuel properties of bend fuels. Alisaraei et al. [13] investigated vibration characteristics of internal combustion engines when ethanol was added to pure diesel fuel with concentration 2, 4, 6, 8, 10 and 12\%. The experiments were realized at 1600, 1700,1800 and $2000 \mathrm{rpm}$ engine speed. The results demonstrate that vibration characteristics of engine block increase between 4,75 at $7,75 \%$ with increase concertation of ethanol as compared with pure diesel and this value achieved more than $8 \%$ with increase engine speed. Ambrós et al. [14] investigated the effect of 10, 20, 30 and 40\% water addition on ethanol in internal combustion engine performance. The ignition advance was adjusted to obtain the best engine torque. The results demonstrate that performed with 20 and $30 \%$ of water addition on ethanol was better performance than commercial ethanol fuel.

\section{METHODOLOGY}

The experimental procedure involves the instrumentation of the engine with two tri-axial accelerometers installed on the $1^{\circ}$ and $5^{\circ}$ fixed bearings of the crankshaft were used in order to acquire data on both transverse and longitudinal displacements of the crankshaft. A hydraulic dynamometer, passive FE model 150s, was used in order to measure engine speed. So as to acquire the vibration signal an LMS Test Lab Software by SIEMENS was used. The Fig. 1 shows the installation of the accelerometers on both sides of the bearings fixing both the crankshaft. The accelerometers used for testing were a piezoelectric accelerometer model Kistler K Shear 8704B100. The tests were carried out on a four-cylinder flex-fuel sparkignition engine naturally aspirated with $1368 \mathrm{~cm}^{3}$ of total displacement. 


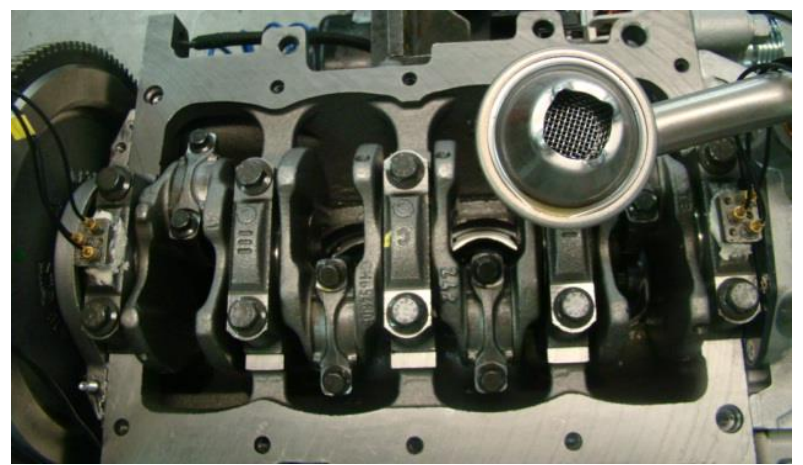

Figure 1 - Installation of the accelerometers in $1^{\circ}$ and $5^{\circ}$ fixed bearings of the crankshaft.

The test was conducted with full load according the International Organization for Standardization ISO 3046-1:2002 [1], which is the standard specifies the test conditions and methods of declaration of power and fuel consumption in internal combustion engines. Data were acquired under the following conditions: water average temperature at around $95{ }^{\circ} \mathrm{C}$ and oil at $135{ }^{\circ} \mathrm{C}$. The test was performed at specific speeds between 1000 to $6000 \mathrm{rpm}$ with increments of $250 \mathrm{rpm}$. SAE 5W30 lubricant oil with gasoline fuel and ethanol fuel were used during the first part of test. The experiment was repeated with SAE $15 \mathrm{~W} 40$ lubricant oil, the same fuel, gasoline and ethanol, and under the same conditions of first part. The test consisted of running the engine dynamometer at specific speed and full load. After stabilizing the conditions of the temperatures of both water and oil, the acquisition of the parameters of vibration signal in accelerometers and other parameters were processed and stored in the Software LMS Test Lab. The Fig. 2 shows the experimental setup scheme.

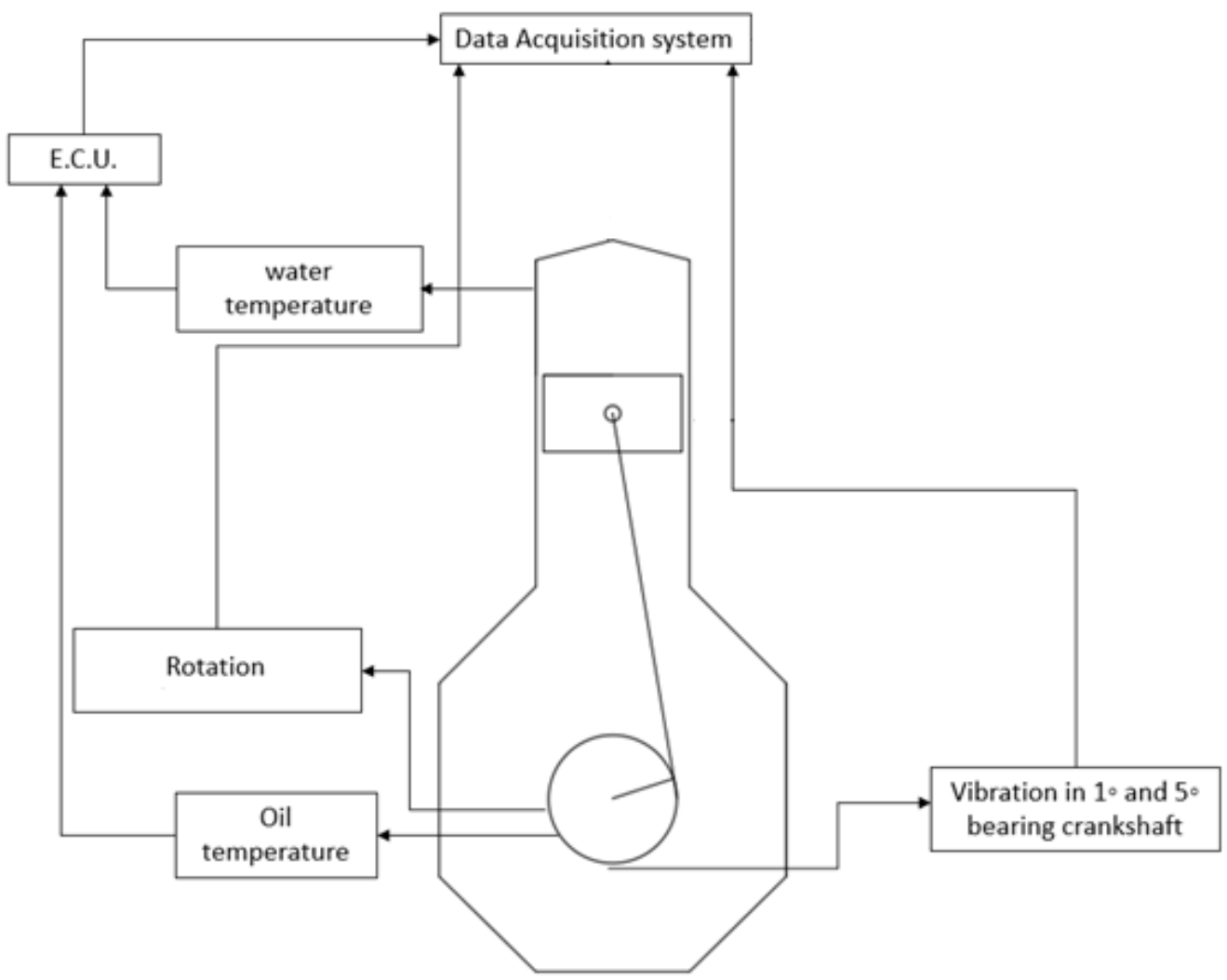

Figure 2 - Experimental setup scheme. 
The analysis of the results consisted in correlating the data of vibrations measured on the $1^{\circ}$ and $5^{\circ}$ fixed bearings of the crankshaft as analyzed as a function of both the rotation of engine, according International Organization for Standardization ISO 3046-1:2002 [1], and the type of oil and fuel used in the tests. The analysis of the vibration data in average of the transverse and longitudinal vibration was done using the Root Mean Square (RMS). The results and discussed will be shown and analyzed in the next section.

\section{RESULTS AND DISCUSSION}

This section will be presented and discussed the results of the vibration measurements on the crankshaft of the engine installed in the dynamometer working in full load according the International Organization for Standardization ISO 3046-1:2002 [1], which is the standard specifies the test conditions and methods of declaration of power and fuel consumption in internal combustion engines, the analysis of the measured parameters is analyzed according to the rotation of the engine, type of fuel and oil used during the tests.

The Figures $3 \mathrm{a}$ and $3 \mathrm{~b}$ shows both transverse and longitudinal vibration measurements of both side of the crankshaft as a function of the engine speed using SAE 5W30 lubricant oil and gasoline fuel.
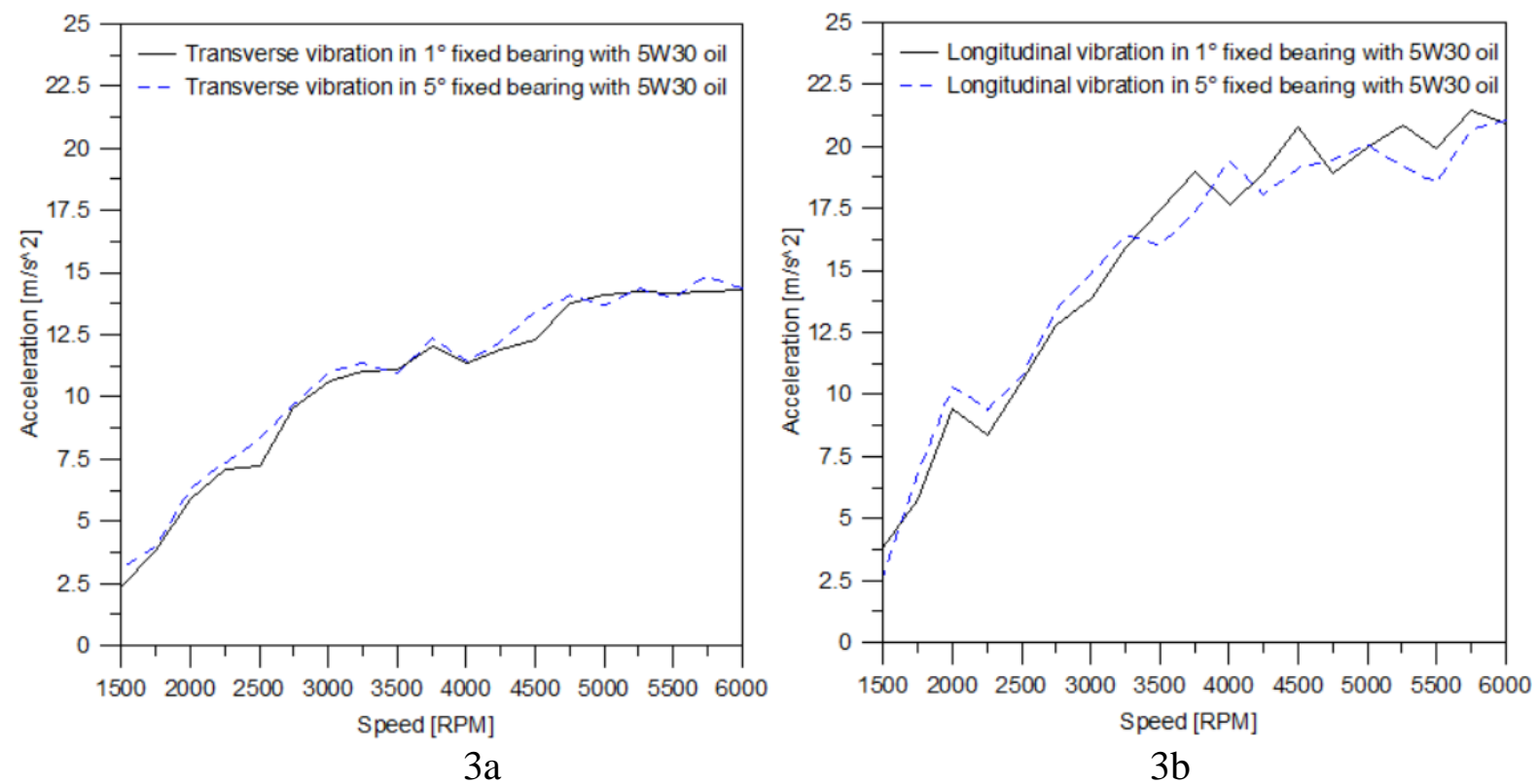

Figure 3 - Vibration measurements a) Transverse axis of crankshaft b) Longitudinal axis of crankshaft with SAE 5W30 lubricant oil and gasoline fuel.

According to figures $3 \mathrm{a}$ and $3 \mathrm{~b}$ the intensity of transversal and longitudinal axis vibrations of engine running with SAE 5W30 lubricant oil and gasoline fuel increases with increase rotation of engine, the RMS values of transverse acceleration measured on the $1^{\circ}$ and $5^{\circ}$ fixed bearings of the crankshaft varied from $2.5 \mathrm{~m} / \mathrm{s}^{2}$ at $1500 \mathrm{rpm}$ to approximately $15 \mathrm{~m} / \mathrm{s}^{2}$ at 6000 $\mathrm{rpm}$ and to longitudinal acceleration measured the value varied $3 \mathrm{~m} / \mathrm{s}^{2}$ at $1500 \mathrm{rpm}$ to approximately $20 \mathrm{~m} / \mathrm{s}^{2}$ at $6000 \mathrm{rpm}$. This increase in vibration is due to increased dynamic load on the bearings with increased engine speed. 
The Figures $4 \mathrm{a}, 4 \mathrm{~b}$ shows transverse and longitudinal vibration measurements of both side of the crankshaft and engine block as a function of engine speed using SAE $15 \mathrm{~W} 40$ lubricant oil and gasoline fuel.
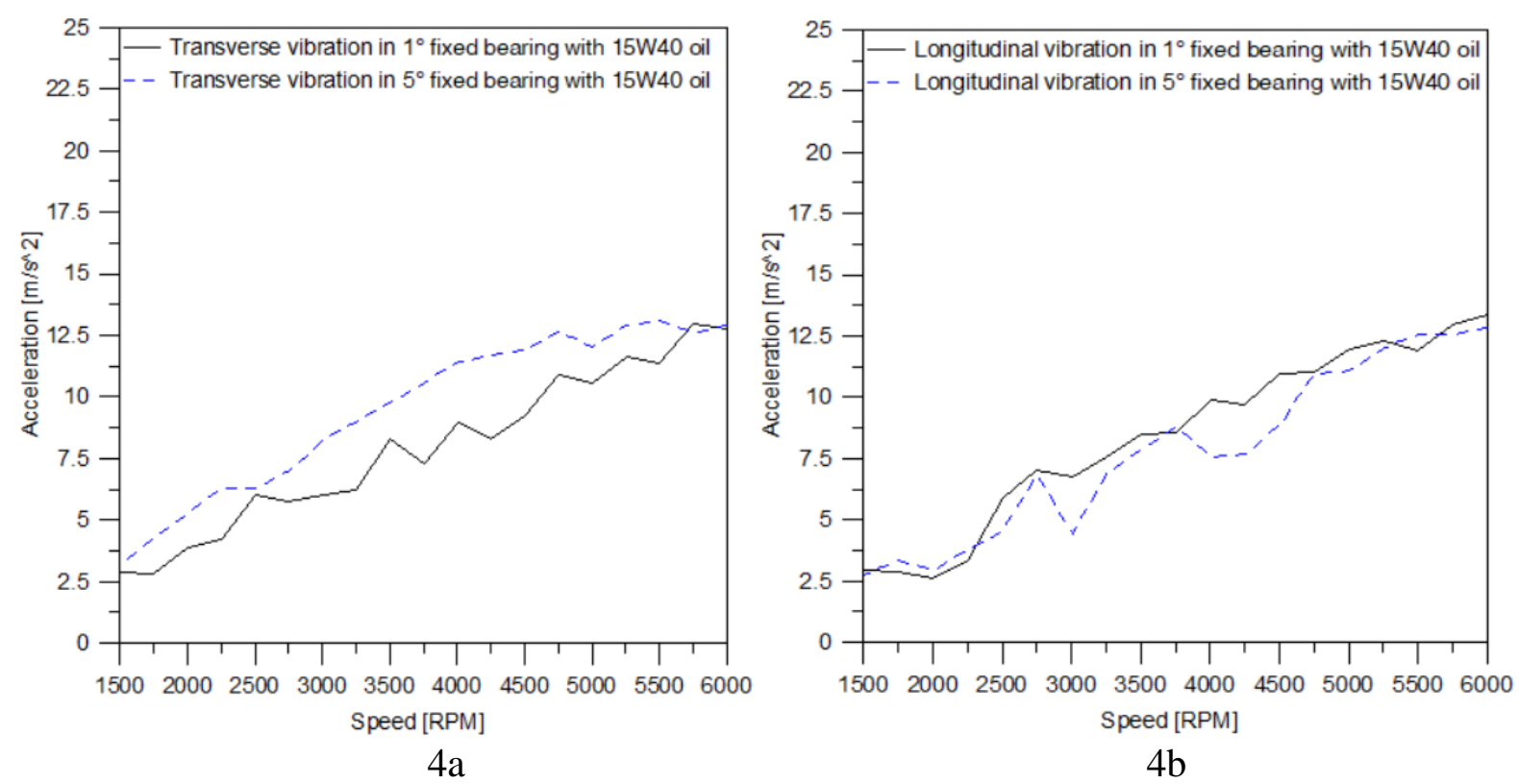

Figure 4 - Vibration measurements a) Transverse axis of crankshaft b) longitudinal axis of crankshaft with SAE 15W40 lubricant oil and gasoline fuel.

According to figures $4 \mathrm{a}$ and $4 \mathrm{~b}$ the intensity of transversal and longitudinal axis vibrations of engine running with SAE 15W40 lubricant oil and gasoline fuel increases with increase rotation of engine, the RMS values of transverse and longitudinal acceleration measured on the $1^{\circ}$ and $5^{\circ}$ fixed bearings of the crankshaft varied from $3 \mathrm{~m} / \mathrm{s}^{2}$ at $1500 \mathrm{rpm}$ to approximately $12.5 \mathrm{~m} / \mathrm{s}^{2}$ at $6000 \mathrm{rpm}$. The tests shown in Figs. 3 and 4 were performed with the same fuel, gasoline, but with different oils SAE 5W30 from the tests shown in Fig. 3 and SAE $15 \mathrm{~W} 40$ in the tests shown in Fig. 4. Analyses of the results of the tests show that the intensity of the transverse and longitudinal vibrations of both side of the crankshaft axis increase as the rotation increases and that such intensity reaches its maximum values close to the regions of maximum torque and maximum power of the engine. The gasoline-fueled engine reaches maximum torque close to $4500 \mathrm{rpm}$ and maximum power close to $6000 \mathrm{rpm}$.

The Figures 5a and 5b show transverse and longitudinal vibration measurements of both side of the crankshaft and engine block as a function of engine speed using SAE 5W30 lubricant oil and ethanol fuel. 

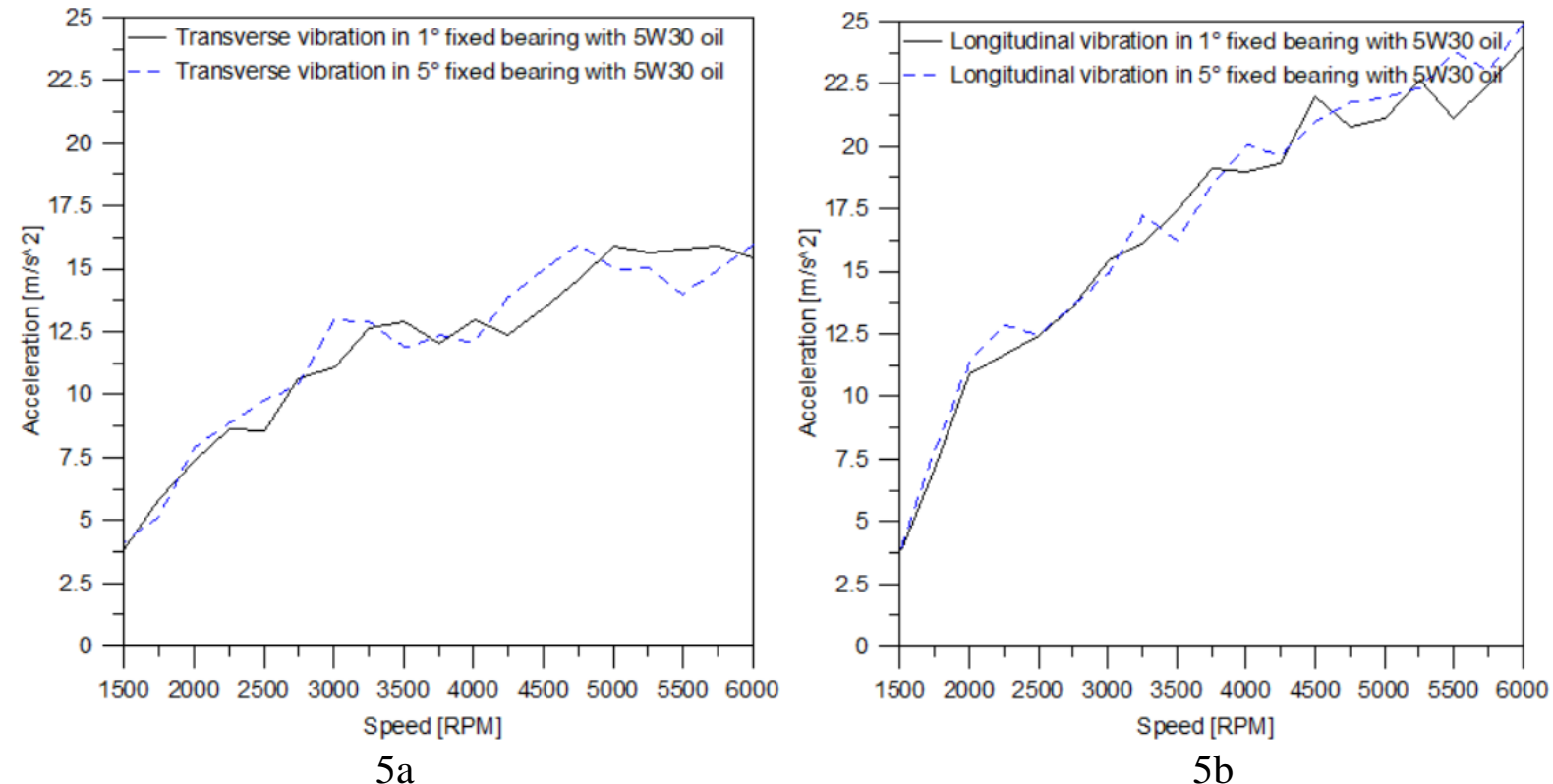

Figure 5 - Vibration measurements a) Transverse of crankshaft axis b) Longitudinal of crankshaft c) Engine block with SAE 5W30 lubricant oil and ethanol fuel.

According to figures $5 \mathrm{a}$ and $5 \mathrm{~b}$ the intensity of transversal and longitudinal axis vibrations of engine running with SAE 5W30 lubricant oil and ethanol fuel increases with increase rotation of engine, the RMS values of transverse acceleration measured on the $1^{\circ}$ and $5^{\circ}$ fixed bearings of the crankshaft varied from $4 \mathrm{~m} / \mathrm{s}^{2}$ at $1500 \mathrm{rpm}$ to approximately $16 \mathrm{~m} / \mathrm{s}^{2}$ at 6000 $\mathrm{rpm}$ and to longitudinal acceleration measured the value varied $4 \mathrm{~m} / \mathrm{s}^{2}$ at $1500 \mathrm{rpm}$ to approximately $24 \mathrm{~m} / \mathrm{s}^{2}$ at $6000 \mathrm{rpm}$.

The Figures $6 \mathrm{a}$ and $6 \mathrm{~b}$ shows transverse and longitudinal vibration measurements of both side of the crankshaft and the engine block as a function of engine speed using SAE 15W40 lubricant oil and ethanol fuel.
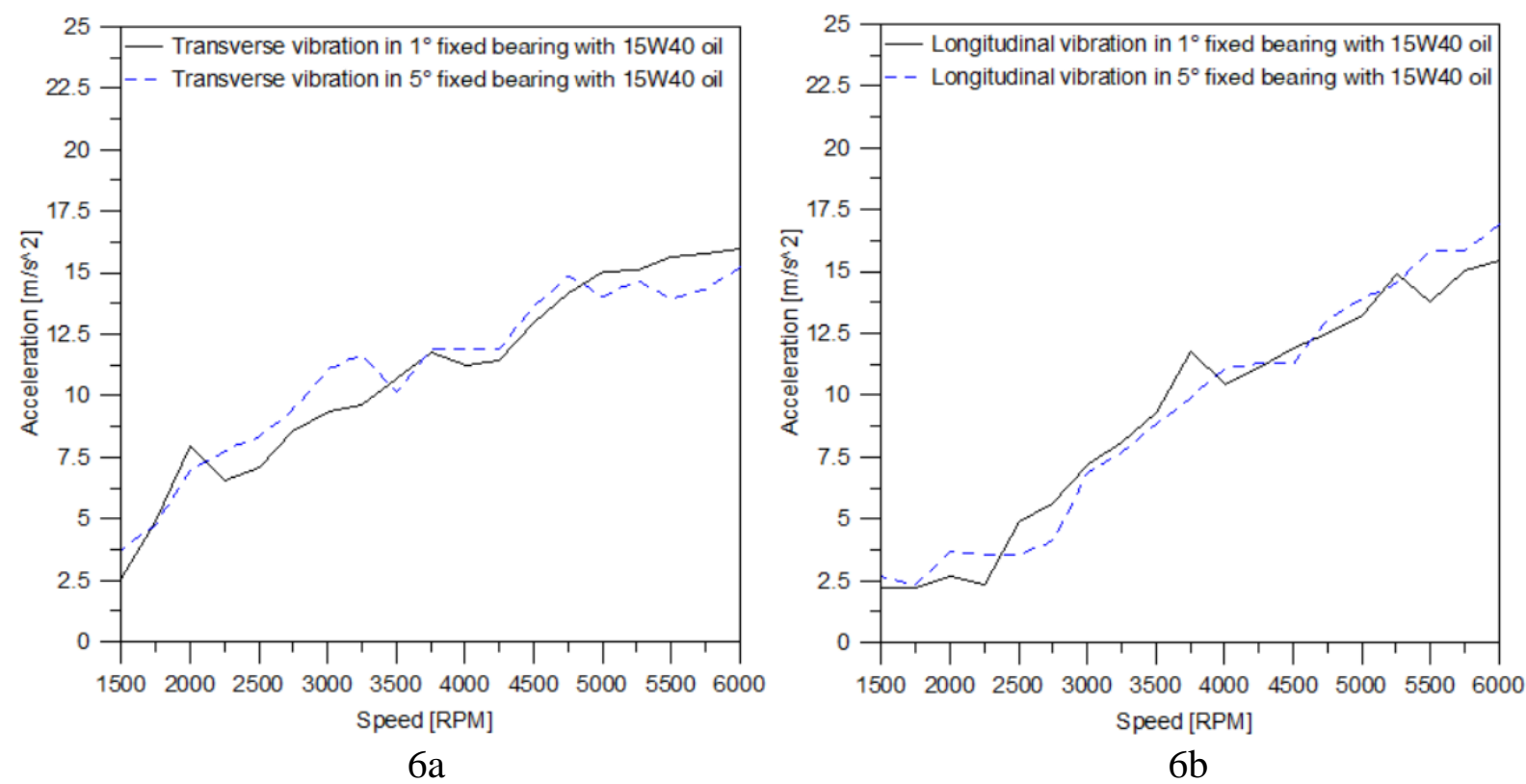

Figure 6 - Vibration measurements a) Transverse of crankshaft axis b) Longitudinal of crankshaft c) Engine block with SAE 15W40 lubricant oil and ethanol fuel. 
According to figures $6 \mathrm{a}$ and $6 \mathrm{~b}$ the intensity of transversal and longitudinal axis vibrations of engine running with SAE 15W40 lubricant oil and ethanol fuel increases with increase rotation of engine, the RMS values of transverse and longitudinal acceleration measured on the $1^{\circ}$ and $5^{\circ}$ fixed bearings of the crankshaft varied from $3 \mathrm{~m} / \mathrm{s}^{2}$ at $1500 \mathrm{rpm}$ to approximately $16 \mathrm{~m} / \mathrm{s}^{2}$ at $6000 \mathrm{rpm}$. The tests shown in Figs. 5 and 6 were performed with the same fuel, ethanol, but with different oils SAE 5W30 in the tests shown in Fig. 5 and SAE $15 \mathrm{~W} 40$ in the tests shown in Fig. 6. It reveals the same vibrational behavior (as shown in Fig. 3 and 4). Alisaraei et al [13] reported that the addition of ethanol into to diesel fuel increases the vibration level of the engine. Alisaraei et al [15] presented results that indicates that fuel type inflow at the level vibration on engine.

With SAE 5W30 lubricant oil and gasoline fuel the average RMS values of acceleration on crankshaft varied from $3 \mathrm{~m} / \mathrm{s}^{2}$ at $1500 \mathrm{rpm}$ to approximately $16 \mathrm{~m} / \mathrm{s}^{2}$ at $6000 \mathrm{rpm}$. With SAE $5 \mathrm{~W} 30$ lubricant oil and ethanol fuel the values varied from $3 \mathrm{~m} / \mathrm{s}^{2}$ at $1500 \mathrm{rpm}$ to approximately $21 \mathrm{~m} / \mathrm{s}^{2}$ at $6000 \mathrm{rpm}$. This represents an average increase of $18 \%$ on transverse vibration and $12 \%$ on longitudinal vibration in the axis of the engine running with ethanol in relation to gasoline both running with SAE 5W30 lubricant.

With SAE 15W40 lubricant oil and gasoline fuel the average RMS values of acceleration on crankshaft varied from $3 \mathrm{~m} / \mathrm{s}^{2}$ at $1500 \mathrm{rpm}$ to approximately $13 \mathrm{~m} / \mathrm{s}^{2}$ at $6000 \mathrm{rpm}$. With SAE $15 \mathrm{~W} 40$ lubricant oil and ethanol fuel the values varied from $3 \mathrm{~m} / \mathrm{s}^{2}$ at $1500 \mathrm{rpm}$ to approximately $16 \mathrm{~m} / \mathrm{s}^{2}$ at $6000 \mathrm{rpm}$. This represents an average increase of $14 \%$ on transverse vibration and $10 \%$ on longitudinal vibration in the axis of the engine running with ethanol in relation to gasoline both running with SAE $15 \mathrm{~W} 40$ lubricant.

\section{CONCLUSIONS}

The vibration intensity of the engine increases with increasing engine speed and load. Being maximum in the regions of torque and power of the engine;

In all operating conditions, the ethanol-run engine has higher vibration intensities than the gasoline-run engine. For the same type of fuel, an oil of higher viscosity attenuates the level of vibration of the engine;

For the same type of fuel, an oil of higher viscosity attenuates the level of vibration of the engine. Measurements show an average increase of $18 \%$ of transverse vibration and $12 \%$ of longitudinal vibration in the crankshaft of the engine running on ethanol in relation to gasoline with low viscosity lubricant and $14 \%$ and $10 \%$ with higher viscosity lubricant.

\section{REFERENCES}

[1] International Organization for Standardization ISO 3046-1, Reciprocating internal combustion engines - Performance - Part 1: Declarations of power, fuel and lubricating 
oil consumptions, and test methods - Additional requirements for engines for general use, 2002.

[2] J.B. Heywood, Internal combustion engine fundamental, $2^{\text {nd }}$ edition, McGraw-Hill, 2003.

[3] C. F. Taylor, Analysis of internal combustion engines, $2^{\text {nd }}$ edition, Edgard Blücher Ltda, 1990.

[4] R. F. Haycock, J. E. Hillier, A. J. Caines, Automotive lubricant reference book, $1^{\text {st }}$ edition, Professional Engineering Publishing, 2004.

[5] X. Wang, Vehicle Noise and Vibration Refinement. 1st edition, Woodhead Publishing Limited, 2010.

[6] T. D. Gillespie, Fundamentals of Vehicle Dynamics, Published by Society of Automotive Engineers, 1992.

[7] K. V. Chandratre, A. Sarkar, B. V. Varade, Experimental Investigation of Fluid Viscosity Effects on Free Damped Vibration, International Engineering Research Journal Page $\mathrm{N}^{\mathrm{o}}$ 1401-1405, Volume:3, Issue:4, April 2015.

[8] A. C. Chavan, D. Thombare, N. Chhapkhane, Experimental investigation of effect of lubricant viscosity on vibrations of plain hydrodynamic journal bearing system, International Journal of Research and Development, 3(4):31-36, April 2015.

[9] J. A. Grajales, H. F. Quintero, C. A. Romero, E. Henao, Engine Diagnosis Based on Vibration Analysis Using Different Fuel Blends, Conference paper: Advances in Condition Monitoring of Machinery in Non-Stationary Operations.pp 267-274, September 2017.

[10] A, Keskin, The Influence of Ethanol Gasoline Blends on Spark Ignition Engine Vibration Characteristics and Noise Emissions, Energy Sources Part A: Recovery (20): 1851-1860, doi: 10.1080/15567030902804749, August 2010.

[11] E. Uludamar, G. Tüccar, K. Aydın, M. Özcanll, Vibration Analysis of a Diesel Engine Fueled with Sunflower and Canola Biodiesels, Advances in Automobile Engineering, volume 5: 137, January 2016.

[12] I. Gravalos, D. Moshou, T. Gialamas, D. Kateris, P. Xyradakis, Z. Tsiropoulos, Vibration effects on spark ignition engine fueled with methanol and ethanol gasoline blends, Journal of agricultural Machinery Science, 2011.

[13] A. T. Alisaraei, A. R. Asi, The effect of added ethanol to diesel fuel on performance, vibration, combustion and knocking of a CI engine, Fuel 185: 718-733, August 2016, doi: 10.1016/j.fuel.2016.08.041.

[14] W.M. Ambrós, T. D. M. Lanzanova, J. L. S. Fagundez, R. L. Sari, D. K. Pinheiro, M. E. S. Martins, N. P. G. Salau, Experimental analysis and modeling of internal combustion engine operating with wet ethanol, Fuel 158: 270-278, May 2015, doi: 10.1016/j.fuel.2015.05.009.

[15] A. T. Alisaraei, B. Ghobadian, T. T. Hashjin, S. S. Mohtasebi, Vibration analysis of a diesel engine using biodiesel and petrodiesel fuel blends, Fuel 102: 414-422, December 2012, doi: 10.1016/j.fuel.2012.06.109. 